\title{
Effect of 2 weeks of endurance training on uncoupling protein 3 content in untrained human subjects
}

Citation for published version (APA):

Schrauwen, P., Russell, A. P., Kornips, E., Boon, N., \& Hesselink, M. K. (2005). Effect of 2 weeks of endurance training on uncoupling protein 3 content in untrained human subjects. Acta Physiologica Scandinavica, 183(3), 273-280. https://doi.org/10.1111/j.1365-201X.2004.01393.x

Document status and date:

Published: 01/01/2005

DOI:

10.1111/j.1365-201X.2004.01393.x

Document Version:

Publisher's PDF, also known as Version of record

Document license:

Taverne

Please check the document version of this publication:

- A submitted manuscript is the version of the article upon submission and before peer-review. There can be important differences between the submitted version and the official published version of record.

People interested in the research are advised to contact the author for the final version of the publication, or visit the DOI to the publisher's website.

- The final author version and the galley proof are versions of the publication after peer review.

- The final published version features the final layout of the paper including the volume, issue and page numbers.

Link to publication

\footnotetext{
General rights rights.

- You may freely distribute the URL identifying the publication in the public portal. please follow below link for the End User Agreement:

www.umlib.nl/taverne-license

Take down policy

If you believe that this document breaches copyright please contact us at:

repository@maastrichtuniversity.nl

providing details and we will investigate your claim.
}

Copyright and moral rights for the publications made accessible in the public portal are retained by the authors and/or other copyright owners and it is a condition of accessing publications that users recognise and abide by the legal requirements associated with these

- Users may download and print one copy of any publication from the public portal for the purpose of private study or research.

- You may not further distribute the material or use it for any profit-making activity or commercial gain

If the publication is distributed under the terms of Article $25 \mathrm{fa}$ of the Dutch Copyright Act, indicated by the "Taverne" license above, 


\title{
Effect of 2 weeks of endurance training on uncoupling protein 3 content in untrained human subjects
}

\author{
P. Schrauwen,' A. P. Russell, ${ }^{2}$ E. Moonen-Kornips, ${ }^{1,3}$ N. Boon' and M. K. C. Hesselink ${ }^{3}$ \\ I Department of Human Biology, Nutrition and Toxicology Research Institute Maastricht (NUTRIM), Maastricht University, Maastricht, \\ The Netherlands \\ 2 Clinique Romande de Réadaptation, Sion, Switzerland \\ 3 Department of Movement Sciences, Nutrition and Toxicology Research Institute Maastricht (NUTRIM), Maastricht University, \\ Maastricht, The Netherlands
}

Received 15 July 2004 , accepted 26 September 2004 Correspondence:

Dr P. Schrauwen, Nutrition and

Toxicology Research Institute

Maastricht (NUTRIM),

Department of Human Biology,

Maastricht University, P.O. Box 616, NL-6200 MD Maastricht,

The Netherlands.

\begin{abstract}
Aim: The mitochondrial uncoupling protein-3 (UCP3) is able to lower the proton gradient across the inner mitochondrial membrane, thereby uncoupling substrate oxidation from ATP production and dissipating energy as heat. What the effect of endurance training on UCP3 is, is still controversial. Endurance-trained athletes are characterized by lower levels of UCP3, but longitudinal studies in rodents reported no effect of endurance training on muscular UCP3 levels. Here, we examined the effect of a 2-week training programme on skeletal muscle UCP3 protein content in untrained human subjects, and hypothesized that UCP3 will be reduced after the training programme.

Methods: Nine untrained men [age: $23.3 \pm 3.2$ years; BMI: $22.6 \pm$ $2.6 \mathrm{~kg} \mathrm{~m}^{-2}$; maximal power output $\left(W_{\max }\right): 3.8 \pm 0.6 \mathrm{~W} \mathrm{~kg}^{-1}$ body weight] trained for 2 weeks. Before and at least $72 \mathrm{~h}$ after the training period, muscle biopsies were taken for determination of UCP3 protein content.

Results: UCP3 protein content tended to be lower after the training programme [ $95 \pm 10$ vs. $109 \pm 12$ arbitrary units (AU), $P=0.08$ ]. Cytochrome $c$ content tended to increase with $33 \%$ in response to endurance training ( $52 \pm 6$ vs. $39 \pm 6 \mathrm{AU}, P=0.08)$. The ratio UCP3 relative to cytochrome $c$ tended to decrease significantly upon endurance training $(2.0 \pm 0.4$ vs. $3.2 \pm 0.6 \mathrm{AU}, P=0.01)$.
\end{abstract}

Conclusion: A short-term (2-week) endurance training programme decreased UCP3 protein levels and significantly reduced the ratio of UCP3 to cytochrome $c$.

Keywords exercise, mitochondria, training, uncoupling protein.
In mitochondria, substrate oxidation results in a proton gradient across the inner mitochondrial membrane, and the potential energy of this proton gradient is used to convert ADP into ATP. However, the coupling between substrate oxidation and ATP production is not $100 \%$ efficient, as part of the built up proton gradient is lowered by so-called uncoupling proteins, thereby dissipating energy as heat. In brown adipose tissue, uncoupling protein-1 (UCP1) is responsible for the well-known thermogenic activity of this tissue (Nedergaard et al. 2001). In 1997, a human muscle-specific uncoupling protein was identified and named UCP3 (Boss et al. 1997). Indeed, UCP3 possesses uncoupling activity when expressed in yeast (Boss et al. 1997) and several associations between the UCP3 gene and its product and energy metabolism have been found (for review see: Schrauwen \& Hesselink 2002). In this context, the effect of acute exercise and endurance training on UCP3 mRNA 
expression and protein content has also been frequently studied. With regard to acute exercise, it was reported in rodents that UCP3 mRNA expression was significantly upregulated 1-3 h after an acute exercise bout (Tsuboyama-Kasaoka et al. 1998, Cortright et al. 1999). Also in humans, 60-90 min of exhaustive one-legged knee extensor exercise resulted in an increase in transcriptional activity and mRNA levels of UCP3 1-4 h post-exercise (Pilegaard et al. 2000). However, it is important to note that during acute exercise, performed in the fasting state, plasma free fatty acid (FFA) levels are increased, and that it was previously shown that fasting leads to a rapid and specific upregulation of UCP3 mRNA (Tunstall et al. 2002). This effect seems to be due to high FFA levels, as infusion of intralipid together with heparin, thereby acutely increasing plasma FFA levels, resulted in a upregulation of UCP3 mRNA after $5 \mathrm{~h}$ (Khalfallah et al. 2000). Therefore, we recently examined the effect of acute exercise on UCP3 mRNA expression in conditions of high (fasting) and low (glucose-fed) FFA levels. Indeed, we found that the upregulation of UCP3 after acute exercise in the fasted state was abolished when plasma FFA levels were suppressed, suggesting that not acute exercise per se, but rather increased FFA levels are responsible for the exercise-induced upregulation of UCP3 (Schrauwen et al. 2002). In line with this finding, Pilegaard et al. (2002) recently showed that UCP3 mRNA expression was significantly increased $2 \mathrm{~h}$ after exercise, but only when muscular glycogen levels were low. As plasma FFA levels were also significantly higher in the low glycogen trial, these results again suggest that changes in plasma FFA and/or glycogen levels instead of exercise per se are responsible for the upregulation of UCP3 mRNA after acute exercise. However, it should be noted that changes in UCP3 mRNA not necessarily result in changes in UCP3 protein.

The effect of regular physical exercise or endurance training on UCP3 is more controversial. In cross-sectional studies, we (Schrauwen et al. 1999) and others (Russell et al. 2002) have shown that UCP3 mRNA expression is significantly lower in endurance-trained athletes compared with lean, untrained human subjects. These results were recently confirmed at the UCP3 protein level (Russell et al. 2003a,b). However, from cross-sectional studies, no hard evidence can be derived on the effect of endurance training per se on UCP3 content, as such evidence requires longitudinal studies. From these longitudinal studies, the effect of endurance training on UCP3 is less clear. At the mRNA level, endurance training has been shown to downregulate (Boss et al. 1998) or not affect UCP3 mRNA (Cortright et al. 1999), whereas at the protein level, endurance training in rodents had either no effect on UCP3 protein levels or increased UCP3 protein in parallel with mitochondrial biogenesis (Tsuboyama-Kasaoka et al. 1998,
Cortright et al. 1999, Jones et al. 2003). Although these data suggest, in contrast to the human cross-sectional studies, no direct effect of endurance training on UCP3 protein levels, differences between species might exist. Two recent studies in humans showed that after 6 weeks of training UCP3 protein levels were decreased when measured using immunofluoresence (Russell et al. 2003a) or when related to mitochondrial content (Fernstrom et al. 2004). To investigate whether the lower UCP3 protein content in trained human subjects reflects a true training-induced effect, we here examined the longitudinal effect of a well-controlled short-term (14 days) training programme, in previously untrained human subjects, on UCP3 protein content. This short duration was chosen to examine whether training effects on UCP3 are primary and not the result of changes in, for example, body weight or fibre type that may occur with long-term training. In addition, a standardized, exercisefree period of at least $72 \mathrm{~h}$ preceded the sampling of muscle for UCP3 protein content measurement. This time frame was chosen to prevent any remnant effect of the final exercise bout on UCP3 protein levels. As endurance training is known to increase mitochondrial density, it is important to consider the level of UCP3 relative to a marker of the latter. This ratio is of importance as the effect of training on UCP3 may be somewhat confounded by a stimulatory effect of training on the number of mitochondria. To this end we also examined the effect of the 2-week endurance training programme on cytochrome $c$ and on the ratio UCP3 : cytochrome $c$. We hypothesized that endurance training results in a lower level of UCP3 and a reduced UCP3 : cytochrome $c$ ratio.

\section{Material and methods}

\section{Subjects}

Nine young, untrained and healthy male subjects participated in this study. Subjects' characteristics at the onset of the study are given in Table 1 . Subjects were recruited by advertisement and were excluded from participation if they had performed aerobic exercise competitively for more than 3 months or were still exercising on a regular basis. The study was approved by the institutional Medical Ethics Committee. Subjects gave their written informed consent after the nature of the procedure was explained.

\section{Experimental protocol}

A week preceding the experimental trial, an incremental test to determine maximal power output $\left(W_{\max }\right)$ and maximal oxygen consumption $\left(V_{\mathrm{O}_{2 m a x}}\right)$ was performed, which was repeated in the week after the experimental trial. 
Table I Subjects characteristics

\begin{tabular}{lcc}
\hline & Mean \pm SEM & Range \\
\hline Age (years) & $23.3 \pm 1.08$ & $19-28$ \\
Height $(\mathrm{m})$ & $1.80 \pm 0.02$ & $1.72-1.89$ \\
Weight $(\mathrm{kg})$ & $73.2 \pm 2.6$ & $59.4-82.3$ \\
BMI $\left(\mathrm{kg} \mathrm{m}^{-2}\right)$ & $22.6 \pm 0.9$ & $18.3-26.2$ \\
Body fat $(\%)$ & $17.7 \pm 2.0$ & $10.1-24.6$ \\
Fat free mass $(\mathrm{kg})$ & $60.1 \pm 2.1$ & $52.8-69.3$ \\
Maximal power output $(\mathrm{W})$ & $272.8 \pm 14.0$ & $225-338$ \\
Maximal power output & $3.7 \pm 0.2$ & $2.8-4.6$ \\
per kg (W kg & & \\
Maximal $\mathrm{Vo}_{2}\left(\mathrm{~L} \mathrm{~min}^{-1}\right)$ & $3.54 \pm 0.18$ & $2.79-4.30$ \\
Maximal heart rate $\left(\right.$ beats $\left.\mathrm{min}^{-1}\right)$ & $191 \pm 4$ & $173-205$ \\
\hline
\end{tabular}

Subjects started with a standardization period for 3 days (days 1-3), during which time a standardized diet was provided and subjects refrained from exercise. In the afternoon of day 3, after a 4 -h fast, the subjects performed a submaximal cycling test at $40 \%$ of their predetermined $W_{\max }$ for $3 \mathrm{~h}$. Substrate oxidation during the test was measured by indirect calorimetry. Before exercise, a resting muscle biopsy was taken from the $\mathrm{m}$. vastus lateralis. Subjects then participated in a 12-day training programme with either $2 \mathrm{~h}$ of endurance exercise or $45 \mathrm{~min}$ of intermittent exercise training, alternating on a daily base. The 3 -h cycling test was also considered as a training day for these untrained subjects. Resting days were incorporated on day 4 and 10 , and the final training session was performed on day 14. This means that subjects trained on days 3, 5-9 and 11-14, making a total of 10 training days. On day 14, the last bout of exercise in the training period was performed in the early morning at 07:00 AM. This resulted in a period of $>72 \mathrm{~h}$ between the last bout of exercise and the sampling of the post-training muscle biopsy. After the training session, subjects again followed a standardization period for 3 days (days 15-17), with the same standardization diet as on day 1-3 and during which subjects refrained from exercise. In the afternoon of day 17 , the subjects again performed a submaximal exercise test at $40 \% W_{\max }$, with substrate oxidation being measured. Again, a muscle biopsy was taken prior to exercise from the $\mathrm{m}$. vastus lateralis.

\section{Diets}

The standardization diet consisted of $30 \%$ energy as fat, $55 \%$ energy as carbohydrate and $15 \%$ energy as protein. Subjects were given a fixed amount of food [1.65 BMR based on Harris \& Benedict (1919) equations] and were asked to eat all the food provided, and nothing else. The diet consisted of breakfast, lunch, ready to use dinner and snacks.

\section{Procedures}

Body composition. Whole body density was determined by underwater weighing in the morning in the fasted state. Body weight was measured with a digital balance with an accuracy of $0.01 \mathrm{~kg}$ (Sauter, type E1200, Albstadt-Ebingen, Germany). Lung volume was measured simultaneously with the helium dilution technique using a spirometer (Volugraph 2000; Mijnhardt, Mannheim, Germany). Percentage body fat was calculated using the equations of Siri (1956).

Maximal performance. Maximum workload ( $\left.W_{\max }\right)$ and maximum oxygen uptake $\left(\mathrm{VO}_{2 \max }\right)$ were determined on an electronically braked cycle ergometer (Lode Excalibur, Groningen, the Netherlands) during an incremental exhaustive exercise test (Kuipers et al. 1989) 1 week before the experimental trial. Oxygen uptake was measured by indirect calorimetry (Oxycon- $\beta$; Mijnhardt). The test was repeated 1 week after the experimental trial.

Indirect calorimetry. During the submaximal exercise test, energy expenditure and substrate oxidation was measured every $15 \mathrm{~min}$ using indirect calorimetry $($ Oxycon- $\beta)$. Energy expenditure during exercise was calculated from oxygen consumption and carbon dioxide production as described previously (Weir 1949). Work efficiency was defined as power/(average energy expenditure). Respiratory exchange ratio (RER) was calculated by dividing $\mathrm{VCO}_{2}$ by $\mathrm{VO}_{2}$.

\section{Training programme}

From day 5 to 14 , subjects reported to the laboratory daily to follow supervised training sessions on cycle ergometers (Lode Excalibur), except for the resting day on day 10. Training consisted of alternating days of interval and endurance training and always started with 7.5 min of warming up at $40 \% W_{\max }$ and ended with 7.5 min of cooling down at $40 \% W_{\max }$. On days 5, 7, 9 and 11 , intermittent exercise training was performed, which consisted of $45 \mathrm{~min}$ of alternating 3-min intervals at $70 \% W_{\max }$ and $35 \% W_{\max }$. At days 6, 8, 12 and 14, exercise consisted of $35 \mathrm{~min}$ at $55 \% W_{\max }$, followed by $35 \mathrm{~min}$ at $50 \% \mathrm{~W}_{\max }$, and $35 \mathrm{~min}$ at $45 \% W_{\max }$, for a total duration of $120 \mathrm{~min}$. The last training session on day 14 took place early in the morning, so that it was finished at least $72 \mathrm{~h}$ before muscle sampling.

\section{Muscle biopsy and analysis}

Muscle biopsies were taken from the mid-thigh region from $\mathrm{m}$. vastus lateralis according to the technique of Bergstrom et al. (1967). Thirty sections of $25 \mu \mathrm{m}$ thickness were cut from the muscle biopsies and homogenized 


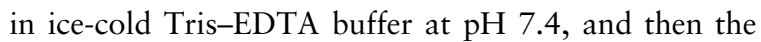
homogenates were sonicated for 15 s. Subsequently, 2 volumes of each skeletal muscle homogenate and 1 volume of SDS-sample buffer were boiled for $4 \mathrm{~min}$. Next, $13 \%$ polyacrylamide gels containing $0.1 \%$ SDS were loaded with equal amounts $(20 \mu \mathrm{g})$ of protein from each sample, and electrophoresis was performed using a Mini-Protean 3 Electrophoresis Cell (Bio-Rad Laboratories, Hercules, CA, USA). After gel electrophoreses, the gel was scanned, and the optical density of the $43-\mathrm{kDa}$ band, previously immuno-identified to represent actin, was assessed. Then, a second gel was prepared and loaded with the sample volume (which had been recalculated based on the optical density of the actin band), after which Western blotting was performed using a Mini Trans-Blot Electrophoretic Transfer Cell (Bio-Rad Laboratories) as described previously (Hesselink et al. 2003). We used a rabbit polyclonal UCP3 antibody (code 1331; kindly provided by LJ Slieker, Eli Lilly) prepared against a 20 -amino acid (aa) peptide (human sequence aa 147-166), which recognizes both the long and the short form of UCP3 and was previously shown not to recognize UCP2 (Hesselink et al. 2003). The antibody was affinitypurified on a Sulfolink column (Pierce; Omnilabo International, Breda, the Netherlands) containing the peptide coupled through a COOH-terminal cysteine. Crossreaction of the antibody with other proteins was checked by examining the entire $5-94-\mathrm{kDa}$ range for additional bands. For a more detailed description of the selectivity and specificity checks see previous reports (Schrauwen et al. 2000, Hesselink et al. 2003). The western blot procedure for the determination of cytochrome $c$ levels was identical to that described for UCP3. For the detection of cytochrome $c$ a mouse monoclonal cytochrome $c$ antibody (BD PharMingen, Woerden, NL, USA) was used. Both UCP3 and cytochrome $c$ were expressed as arbitrary units (AU).

\section{Intramyocellular lipid measurement}

Image-guided localized single voxel ${ }^{1} \mathrm{H}$-MRS was performed in the $\mathrm{m}$. vastus lateralis before the 3 -h cycling test, both before and after training. The measurements were performed on a $1.5 \mathrm{~T}$ whole body scanner (Intera; Philips Medical Systems, Best, the Netherlands). Details of the measurement have been described previously (Schrauwen-Hinderling et al. 2003).

\section{Blood analyses}

A fasting blood sample was taken at 8 AM 1 day prior to the exercise testing. For determination of FFA, glycerol and glucose, blood was collected in tubes containing $30 \mu \mathrm{l}$ of $0.2 \mathrm{M}$ EDTA. Plasma was immediately centrifuged at high speed, frozen in liquid nitrogen and stored at $-80^{\circ} \mathrm{C}$ for later analyses. Insulin concentrations were measured using radioimmunoassay (RIA) (Linco Research, St Charles, MO, USA). FFA were determined using the Wako Nefa C testkit (Wako Chemicals, Neuss, Germany).

Plasma glucose was determined using the hexokinase method (LaRoche, Basel, Switzerland) and glycerol using the GPO-trinder (Sigma, St Louis, MO, USA).

\section{Statistics}

Data are presented as mean \pm standard error of the mean (SEM). The effect of the training programme on selected variables was tested using paired Student's $t$ tests. Pearson correlation coefficients were calculated to determine the relationship between selected variables. $P$-values $<0.05$ were considered statistically significant.

\section{Results}

\section{Energy metabolism}

Maximal power output $\left(W_{\max }\right)$ increased after the training programme $(272.8 \pm 14.0$ vs. $281.7 \pm$ $13.4 \mathrm{~W}$ pre- and post-training, respectively, $P=0.08$ ). Maximal oxygen consumption $\left(V_{\mathrm{O}_{2 \max }}\right)$ was not affected by the training programme $(3.54 \pm 0.18$ vs. $3.52 \pm 0.15 \mathrm{~L} \mathrm{~min}^{-1}$ in pre- and post-training, respectively, ns). Energy expenditure during exercise was not significantly affected by the training programme $\left(36.0 \pm 1.7\right.$ vs. $35.3 \pm 1.4 \mathrm{~kJ} \mathrm{~min}^{-1}$ in pre- and posttraining, respectively, ns). Work efficiency (power/ energy expenditure) was also not different before and after training (18.2 \pm 0.5 vs. $19.1 \pm 0.5 \%$ in pre- and post-training, respectively, ns). Similarly, RER during exercise was not significantly affected by the training programme $(0.90 \pm 0.01$ vs. $0.91 \pm 0.01$ in pre- and post-training, respectively, ns).

\section{Blood parameters}

There were no significant differences before and after training in the fasting plasma values of insulin $\left(7.5 \pm 1.1\right.$ vs. $7.4 \pm 1.1 \mu \mathrm{U} \mathrm{mL}^{-1}$, ns), FFA (355 \pm 48 vs. $349 \pm 47 \mu \mathrm{mol} \mathrm{L}{ }^{-1}$, ns) and glycerol (68 \pm 6 vs. $71 \pm 6 \mu \mathrm{mol} \mathrm{L}^{-1}$, ns). However, there was a tendency of decreased fasting plasma glucose after training $\left(5.23 \pm 0.08\right.$ vs. $\left.5.06 \pm 0.11 \mathrm{mmol} \mathrm{L}^{-1}, P=0.06\right)$.

\section{Muscle metabolites}

As previously published (Schrauwen-Hinderling et al. 2003), 2 weeks of endurance training resulted in a significant $42 \pm 14 \%$ increase in intramyocellular lipid (IMCL) content $(0.35 \pm 0.02$ vs. $0.49 \pm 0.04 \%$ of the 
(a)

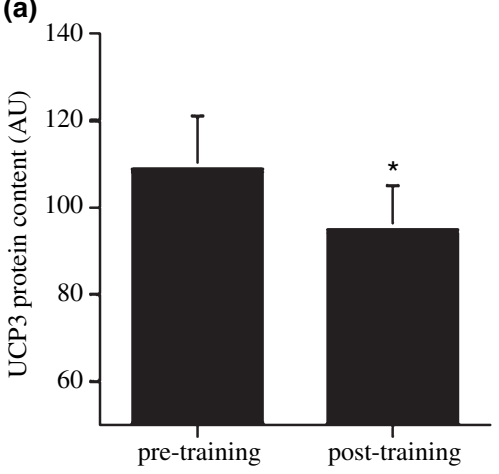

(b)

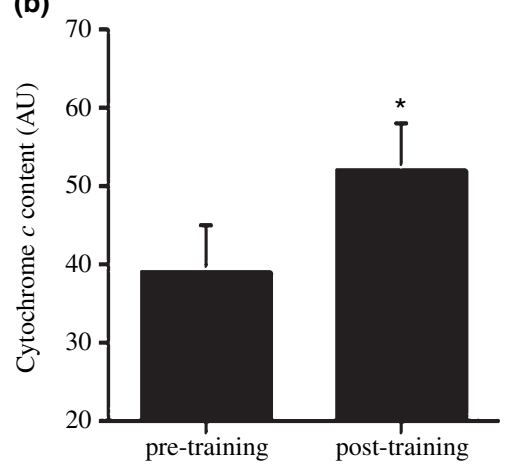

(c)

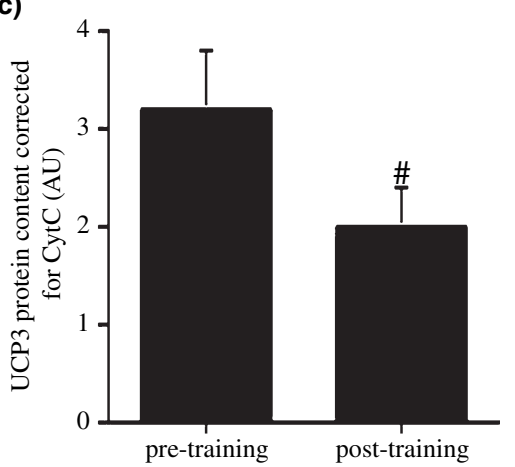

Figure I The effect of endurance training on (a) UCP3 protein, (b) cytochrome $c$ protein and (c) the ratio of UCP3 to cytochrome $c$. All values are in arbitrary units. $P<0.05$.

water reference signal in pre- and post-training, respectively, $P<0.05$ ).

UCP3 protein content was not significantly affected by the 2-week training programme. However, there was a tendency for UCP3 to decrease by $13 \%$ in response to the training programme $(109 \pm 12$ vs. $95 \pm 10 \mathrm{AU}$ in pre- and post-training, respectively, $P=0.08$, Fig. 1 a). The 2-week training programme did not have a statistically significant effect on cytochrome $c$. However, cytochrome $c$ content increased with $33 \%$ in response to endurance training ( $39 \pm 6$ vs. $52 \pm 6 \mathrm{AU}$ in preand post-training, respectively, $P=0.08$, Fig. 1b). As a result, the content of UCP3 relative to cytochrome $c$ decreased significantly upon endurance training (3.2 \pm 0.6 vs. $2.0 \pm 0.4 \mathrm{AU}$ in pre- and post-training, respectively, $P<0.01$, Fig. 1c).

There were no correlations between UCP3 protein content and $W_{\max }$ or $V_{\mathrm{O}_{2 \max }}$. However, in accordance with previous reports (Schrauwen et al. 1999, Russell et al. 2002), we did find a negative correlation between UCP3 protein content before training and work efficiency during exercise $(r=-0.68, P<0.05$, Fig. 2$)$. The training-induced changes in UCP3 protein content were not related to changes in energy expenditure, work efficiency or RER. In addition, no correlations between UCP3 and plasma substrates or IMCL levels were found (data not shown, all $P>0.05$ ).

\section{Discussion}

Several studies have shown that acute exercise leads to an upregulation of UCP3 mRNA expression (Tsuboyama-Kasaoka et al. 1998, Cortright et al. 1999, Pilegaard et al. 2000, 2002, Zhou et al. 2000, Schrauwen et al. 2002, Jones et al. 2003, Noland et al. 2003). However, this upregulation is dependent on plasma FFA and/or muscular glycogen levels (Pilegaard et al. 2002, Schrauwen et al. 2002), suggesting that acute exercise per se has no stimulatory effect on UCP3 mRNA

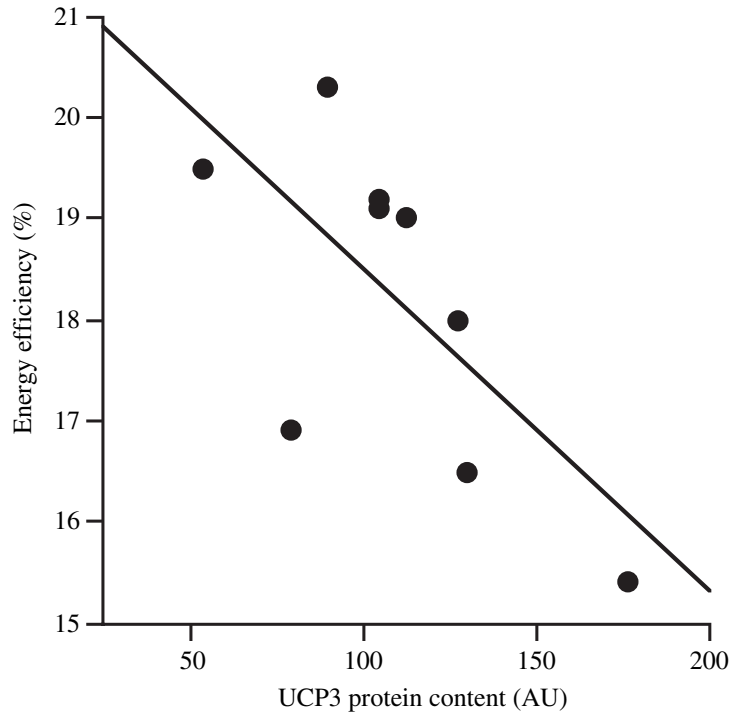

Figure 2 Relationship between pre-training values of UCP3 protein content (arbitrary content) and work efficiency (\%) during exercise $(r=-0.68, P<0.05)$.

expression. With respect to this, the effect of endurance training on UCP3 content is of particular interest, but still controversial. Cross-sectional studies have found that UCP3 mRNA expression was significantly lower in endurance-trained athletes and that the level of UCP3 mRNA expression was very strongly and negatively correlated with aerobic capacity (Schrauwen et al. 1999, Russell et al. 2002). Recently, we extended these findings to the protein levels, showing $46 \%$ lower UCP3 protein levels in endurance-trained athletes compared with untrained subjects (Russell et al. 2003b). However, results from longitudinal studies are less consistent. Boss et al. (1998) showed that UCP3 mRNA expression was significantly lower after 8 weeks of endurance training in rats, but other studies showed no effect of training on UCP3 in rodents (TsuboyamaKasaoka et al. 1998, Cortright et al. 1999, Jones et al. 
2003). Here, we show in human subjects that 14 days of endurance training did not affect the UCP3 protein levels significantly. However, we found a tendency for the absolute UCP3 protein content to be reduced after the 2-week training programme. As endurance training is known to affect mitochondrial density, it is important to consider the level of UCP3 per mitochondria. To obtain an estimate on the latter, we determined the ratio of UCP3 relative to cytochrome $c$. In the present study, we found that the ratio of UCP3 to cytochrome $c$ was significantly reduced after the 2 weeks of endurance training. A possible explanation for these differing results might amongst others be a remnant (stimulatory) effect of the last bout of exercise on UCP3. Thus, Tsuboyama-Kasaoka et al. (1998) showed that after 2 weeks of training, UCP3 mRNA was upregulated 1418 -fold when measured $3 \mathrm{~h}$ after the last exercise bout, but returned to sedentary levels when measured $22 \mathrm{~h}$ after the last exercise bout (Tsuboyama-Kasaoka et al. 1998). Similarly, Cortright et al. (1999) and Jones et al. (2003) measured UCP3 levels within $24 \mathrm{~h}$ after the last exercise bout. In the present study, muscle biopsies were taken $>72 \mathrm{~h}$ after the last exercise bout, to prevent any remnant effect of the last exercise bout on UCP3 protein content. During these $72 \mathrm{~h}$, subjects received a standardized diet and refrained from physical activity. In all reports that showed no effect or an upregulation of UCP3 after training, the period between the last exercise bout and muscle sampling was less than $48 \mathrm{~h}$, providing a likely explanation for the differing results. Taken together, our data suggests that in humans, endurance training may reduce mitochondrial UCP3 protein content, which is in accordance with the reported lower UCP3 levels in endurance-trained athletes, and with the recent reports showing decreased UCP3 protein (measured using immunofluorescence) (Russell et al. 2003a) and decreased UCP3 relative to citrate synthase (Fernstrom et al. 2004) after a 6-week training programme. In addition, the present study also shows that the training-induced reduction of the ratio of UCP3 to cytochrome $c$ is a very early response to training. We have used a well-controlled and very short training programme to be able to distinguish between primary training effects and effects of altered body composition and body weight that may occur after long-term training.

A downregulation of UCP3 with endurance training is also expected from the finding that subjects with a complete chronic lesion of the cervical spinal cord had fourfold higher UCP3 mRNA levels compared with healthy subjects, indicating that muscle inactivity leads to a pronounced upregulation of UCP3. Interestingly, when these tetraplegic subjects were exercise-trained for 8 weeks, using electrically stimulated leg cycling, UCP3 mRNA expression was downregulated by $\sim 50 \%$
(Hjeltnes et al. 1999). Also in rats, denervation (and thus inactivation) resulted in a $331 \%$ increase in UCP3 mRNA expression in gastrocnemius muscle (Cortright et al. 1999).

The reason for the underlying mechanisms responsible for the tendency to downregulate UCP3 with endurance training cannot be deduced from the present study. We (Schrauwen et al. 2001) and others (HimmsHagen \& Harper 2001, Goglia \& Skulachev 2003) have suggested that UCP3 has its function in fatty acid metabolism, serving as an exporter of fatty acid anions from the mitochondrial matrix. As a side-effect of exporting fatty acid anions, UCP3 lowers the proton gradient. Although it is well known that endurance training improves fatty acid oxidative capacity, we did not yet detect an effect of our endurance training programme on fat oxidation during submaximal exercise. The lack of such effect is most likely explained by the short duration of the training programme. However, it cannot be excluded that the reduction of UCP3 is part of an early muscular adaptation to improve fat oxidative capacity, that cannot yet be detected at the wholebody level. For this reason, the hypothesis that the tendency of reduced UCP 3 was related to an improved fat oxidative capacity cannot be tested in the present study. Alternatively, it has been suggested that UCP3 protein content is upregulated by high plasma FFA levels and/or high levels of IMCL. In this context, it is important to note that our 2-week training programme resulted in an increase in IMCL levels (SchrauwenHinderling et al. 2003) and no change in plasma FFA, and these parameters were not related to the change in UCP3 protein levels. Therefore, it is unlikely that the reduced UCP3 protein content after endurance training was due to altered levels of plasma FFA and/or IMCLs.

In our previous reports (Schrauwen et al. 1999, Russell et al. 2002) in which we showed that UCP3 mRNA expression was significantly lower in endurance-trained athletes compared with lean, untrained human subjects, we also found that UCP3 mRNA expression was related to work efficiency. Although there is at present little evidence that UCP3 plays an important primary role in the regulation of human energy expenditure, it cannot be excluded that a reduction in UCP3 would, as a side-effect of its putative physiological function as mentioned above, result in improved work efficiency. In this regard, it is interesting to note that we found a negative correlation between baseline UCP3 protein content and gross work efficiency during exercise, which is a confirmation of earlier findings (Schrauwen et al. 1999, Russell et al. 2002). Unfortunately, in the present study, we did not determine delta energy efficiency, which might be a better estimate of energy efficiency. Interestingly, however, in the study of Fernstrom et al. (2004), the reduction in UCP3 protein content relative to 
mitochondrial density after 6 weeks of training was also accompanied by a reduction in uncoupled respiration. Together, these finding indicates that endurance training elicits physiological adaptations that allow a reduced mitochondrial UCP3 protein content and improved mitochondrial work/energy efficiency. Therefore, further studies are needed to examine the exact role of UCP3 in determining energy efficiency in humans.

In conclusion, we show that a short-term endurance training programme significantly reduces the ratio of UCP3 to cytochrome $c$ and tends to decrease the absolute level of UCP3 protein. These results indicate that the reduction in UCP3 is a very early response to endurance training.

The research of Dr P. Schrauwen has been made possible by fellowship of the Royal Netherlands Academy of Arts and Sciences. We thank Lawrence J Slieker from Eli Lilly and Company for providing us with the UCP3 antibody.

\section{References}

Bergstrom, J., Hermansen, L., Hultman, E. \& Saltin, B. 1967. Diet, muscle glycogen and physical performance. Acta Physiol Scand 71, 140-150.

Boss, O., Samec, S., Paoloni-Giacobino, A. et al. 1997. Uncoupling protein-3: a new member of the mitochondrial carrier family with tissue-specific expression. FEBS Lett 408, $39-42$.

Boss, O., Samec, S., Desplanches, D. et al. 1998. Effect of endurance training on mRNA expression of uncoupling proteins 1, 2 and 3 in the rat. FASEB J 12, 335-339.

Cortright, R.N., Zheng, D., Jones, J.P. et al. 1999. Regulation of skeletal muscle UCP-2 and UCP-3 gene expression by exercise and denervation. Am J Physiol Endocrinol Metab 276, E217-E221.

Fernstrom, M., Tonkonogi, M. \& Sahlin, K. 2004. Effects of acute and chronic endurance exercise on mitochondrial uncoupling in human skeletal muscle. J Physiol 554, 755763.

Goglia, F. \& Skulachev, V.P. 2003. A function for novel uncoupling proteins: antioxidant defense of mitochondrial matrix by translocating fatty acid peroxides from the inner to the outer membrane leaflet. FASEB J 17, 1585-1591.

Harris, J.A. \& Benedict, F.G. 1919. A Biometric Study of Basal Metabolism in Man. Carnegie Institution of Washington, Washington, DC.

Hesselink, M.K.C., Greenhaff, P.L., Constantin-Teodosiu, D. et al. 2003. Increased uncoupling protein 3 content does not affect mitochondrial function in human skeletal muscle in vivo. J Clin Invest 111, 479-486.

Himms-Hagen, J. \& Harper, M.E. 2001. Physiological role of UCP3 may be export of fatty acids from mitochondria when fatty acid oxidation predominates: an hypothesis. Exp Biol Med (Maywood) 226, 78-84.

Hjeltnes, N., Fernström, M., Zierath, J.R. \& Krook, A. 1999. Regulation of UCP2 and UCP 3 by muscle disuse and physical activity in tetraplegic subjects. Diabetologia 42, 826-830.
Jones, T.E., Baar, K., Ojuka, E., Chen, M. \& Holloszy, J.O. 2003. Exercise induces an increase in muscle UCP3 as a component of the increase in mitochondrial biogenesis. Am J Physiol Endocrinol Metab 284, E96-E101.

Khalfallah, Y., Fages, S., Laville, M., Langin, D. \& Vidal, H. 2000. Regulation of uncoupling protein-2 and uncoupling protein-3 mRNA expression during lipid infusion in human skeletal muscle and subcutaneous adipose tissue. Diabetes 49, 25-31.

Kuipers, H., Saris, W.H.M., Brouns, F., Keizer, H.A. \& ten Bosch, C. 1989. Glycogen synthesis during exercise and rest with carbohydrate feeding in males and females. Int J Sports Med 10, S63-S67.

Nedergaard, J., Golozoubova, V., Matthias, A., Asadi, A., Jacobsson, A. \& Cannon, B. 2001. UCP1: the only protein able to mediate adaptive non-shivering thermogenesis and metabolic inefficiency. Biochim Biophys Acta 1504, 82-106.

Noland, R.C., Hickner, R.C., Jimenez-Linan, M. et al. 2003. Acute endurance exercise increases skeletal muscle uncoupling protein-3 gene expression in untrained but not trained humans. Metabolism 52, 152-158.

Pilegaard, H., Ordway, G.A., Saltin, B. \& Neufer, P.D. 2000. Transcriptional regulation of gene expression in human skeletal muscle during recovery from exercise. Am J Physiol Endocrinol Metab 279, E806-E814.

Pilegaard, H., Keller, C., Steensberg, A. et al. 2002. Influence of pre-exercise muscle glycogen content on exercise-induced transcriptional regulation of metabolic genes. J Physiol 541, 261-271.

Russell, A., Wadley, G., Snow, R. et al. 2002. Slow component of $[\mathrm{V}] \mathrm{O}(2)$ kinetics: the effect of training status, fibre type, UCP3 mRNA and citrate synthase activity. Int J Obes Relat Metab Disord 26, 157-164.

Russell, A.P., Somm, E., Praz, M. et al. 2003a. UCP3 protein regulation in human skeletal muscle fibre types I, IIa and IIx is dependent on exercise intensity. J Physiol 550, 855-861.

Russell, P., Wadley, G., Hesselink, M.K.C. et al. 2003b. UCP3 protein expression is lower in type I, IIa and IIx muscle fiber types of endurance-trained compared to untrained subjects. Pflugers Archiv Eur J Physiol 445, 563-569.

Schrauwen, P. \& Hesselink, M. 2002. UCP2 and UCP3 in muscle controlling body metabolism. J Exp Biol 205, 2275-2285.

Schrauwen, P., Troost, F.J., Xia, J., Ravussin, E. \& Saris, W.H. 1999. Skeletal muscle UCP2 and UCP3 expression in trained and untrained male subjects. Int J Obes Relat Metab Disord 23, 966-972.

Schrauwen, P., Schaart, G., Saris, W.H. et al. 2000. The effect of weight reduction on skeletal muscle UCP2 and UCP3 mRNA expression and UCP3 protein content in Type II diabetic subjects. Diabetologia 43, 1408-1416.

Schrauwen, P., Saris, W.H. \& Hesselink, M.K. 2001. An alternative function for human uncoupling protein 3: protection of mitochondria against accumulation of nonesterified fatty acids inside the mitochondrial matrix. FASEB J 15, 2497-2502.

Schrauwen, P., Hesselink, M.K., Vaartjes, I. et al. 2002. Effect of acute exercise on uncoupling protein 3 is a fat metabolism- mediated effect. Am J Physiol Endocrinol Metab 282, E11-E17. 
Schrauwen-Hinderling, V.B., Schrauwen, P., Hesselink, M.K. et al. 2003. The increase in intramyocellular lipid content is a very early response to training. J Clin Endocrinol Metab 88, 1610-1616.

Siri, W.E. 1956. The gross composition of the body. Adv Biol Med Physiol 4, 239-280.

Tsuboyama-Kasaoka, N., Tsunoda, N., Maruyama, K. et al. 1998. Up-regulation of uncoupling protein 3 (UCP3) mRNA by exercise training and down-regulation of UCP3 by denervation in skeletal muscles. Biochem Biophys Res Commun 247, 498-503.
Tunstall, R.J., Mehan, K.A., Hargreaves, M., Spriet, L.L. \& Cameron-Smith, D. 2002. Fasting activates the gene expression of UCP3 independent of genes necessary for lipid transport and oxidation in skeletal muscle. Biochem Biophys Res Commun 294, 301-308.

Weir, J.B. 1949. New methods for calculating metabolic rate with special reference to protein metabolism. J Physiol 109, 1-9.

Zhou, M., Lin, B.Z., Coughlin, S., Vallega, G. \& Pilch, P.F. 2000. UCP-3 expression in skeletal muscle: effects of exercise, hypoxia, and AMP-activated protein kinase. Am J Physiol Endocrinol Metab 279, E622-E629. 